The Geneva Papers on Risk and Insurance, 17 (No. 62, January 1992), 26-39

\title{
A Two Decade Comparison of Work After Retirement in the United States*
}

\author{
by Kathryn Anderson, ${ }^{* *}$ Richard Burkhauser*** and George Slotsve ${ }^{* *}$
}

\section{Introduction}

The United States like many Western European countries saw the post World War II slide in the labor force participation rates of older males accelerate in the 1970s. A combination of substantial increases in social security retirement benefits, an increase in the coverage and in the size of employer pension benefits, and a decade of slow economic growth all influenced this trend. But the aging of the baby boom generation and concern over the pressure that the early retirement of this generation will put on the social security system led policymakers in the 1980s to review the United States retirement system.

Among the changes that have already been made are a prohibition on mandatory retirement rules based on age; reductions in the penalty in lost social security benefits from one dollar for every two dollars earned to one dollar for every three dollars earned above the social security earnings maximum and an increase in the actuarial benefit paid those who postpone acceptance of social security benefits past age 65. More importantly, the 1983 Amendments to the Social Security Act provide for a gradual increase, beginning at the turn of the century, in the age at which full social security benefits can be taken from age 65 to age 67.

The great majority of analyses done on the retirement process in the United States come from 1970s data and concentrate on the transition from work to retirement. Part of this literature includes simulations of the effects of the 1983 Amendments on retirement age. The results suggest that they will have a very small effect on the age at which men retire from the labor force. (See Burtless and Moffitt, 1984; Fields and Mitchell, 1984; Gustman and Steinmeier, 1985). What we suggest here is that while this may be the case, this legislation and other economic incentives may still importantly affect work at older ages, even if they have only a small effect on retirement age.

* A first draft of this paper was presented at the European Society of Population Economists Meeting in Pisa June 1991. This paper was written while Burkhauser was a Fellow at the Netherlands Institute for Advanced Study in the Humanities and Social Sciences, Wassenaar, The Netherlands. This research was supported by the National Science Foundation as part of the Event History Workshop of the Institute for Survey Research, the University of Michigan. We thank workshop members, especially Greg Duncan and Nancy Tuma, for their comments on earlier versions of this paper.

** Vanderbilt University.

*** Syracuse University. 
This somewhat paradoxical pronouncement makes more sense when it is recognized that for many men work does not end with retirement. Recent studies have shown that in the 1970s a significant percentage of men returned to work following retirement from a fulltime job (Quinn, Burkhauser and Myers, 1990; Ruhm, 1991). Hence, in evaluating the importance of policy changes on the work effort of older men in the 1990s and beyond, it is critical to consider not only how such decisions affect the timing of retirement but also how they influence the decision to return to work. While the few studies of work after retirement cited above are recent, the data used in these analyses are not. No studies have looked at the work effort of those who retired in the 1980s. Here we used data from the Panel Study of Income Dynamics to trace this phenomena from 1968 through 1986. With these data we not only confirm that work after retirement was an important event in the 1970 s, but that it became an even more important event in the 1980 s.

We first sketch a model of retirement that incorporates possible return to work and then use a hazard model to estimate the duration from retirement to market work for older men who held full-time employment and retired between 1968 and 1986. We show that economic variables commonly associated with the retirement decision also influence the decision to return to work, including social security and employer pension benefits. We then compare the characteristics of a worker's last full-time job with his first post-retirement job. We find that the most important difference between the two is that post-retirement jobs are much more likely to be part-time. Based on these findings we suggest policy changes that are likely to encourage work after retirement in the 1990 s.

\section{Trends in the labor force participation of older men: 1940-1989}

Table 1 is based on decennial census data and on unpublished data from the Current Population Survey. It shows the yearly labor force participation rates of men of ages between 55 and 72 from 1940 to 1989. If one defines normal retirement age as the first age at which at least one-half of a given age group are out of the labor force then normal retirement occurred at age 70 in 1950 . By 1960 normal retirement age had fallen to age 66 and by 1970 it was age 65 . By the mid-1970s it had fallen another year to age 64 . In the early 1980 s normal retirement age fell to age 63 and by the end of the decade was nearing age 62 . This measure of normal retirement age captures part of the trend in work effort over the past five decades but may not reflect what appears to be a break in the steady slide in the work effort of older men in the United States.

As Table 1 shows, this downward trend accelerated in the 1970s. But the 1980s appear to tell a different story. The decade of the 1980 s was torn by major economic events. The first part of the decade was dominated by the deepest recession since the 1930s. One might expect this to have further accelerated the decline in the work effort of older men, but as can be seen, while participation rates continued to decline during this period, at most ages they did so at a slower pace. More surprising is what has happened during the second part of the decade, a period dominated by the longest economy recovery of the century. Table 1 suggests that during this period the long trend in falling participation rates may have ended. For many of the older age groups, drops in labor force participation rates stopped in the mid-1980s and have slightly increased thereafter. In 1989, labor force participation rates equaled or exceeded labor force participation rates in 1984 for five of the seven oldest age categories. 


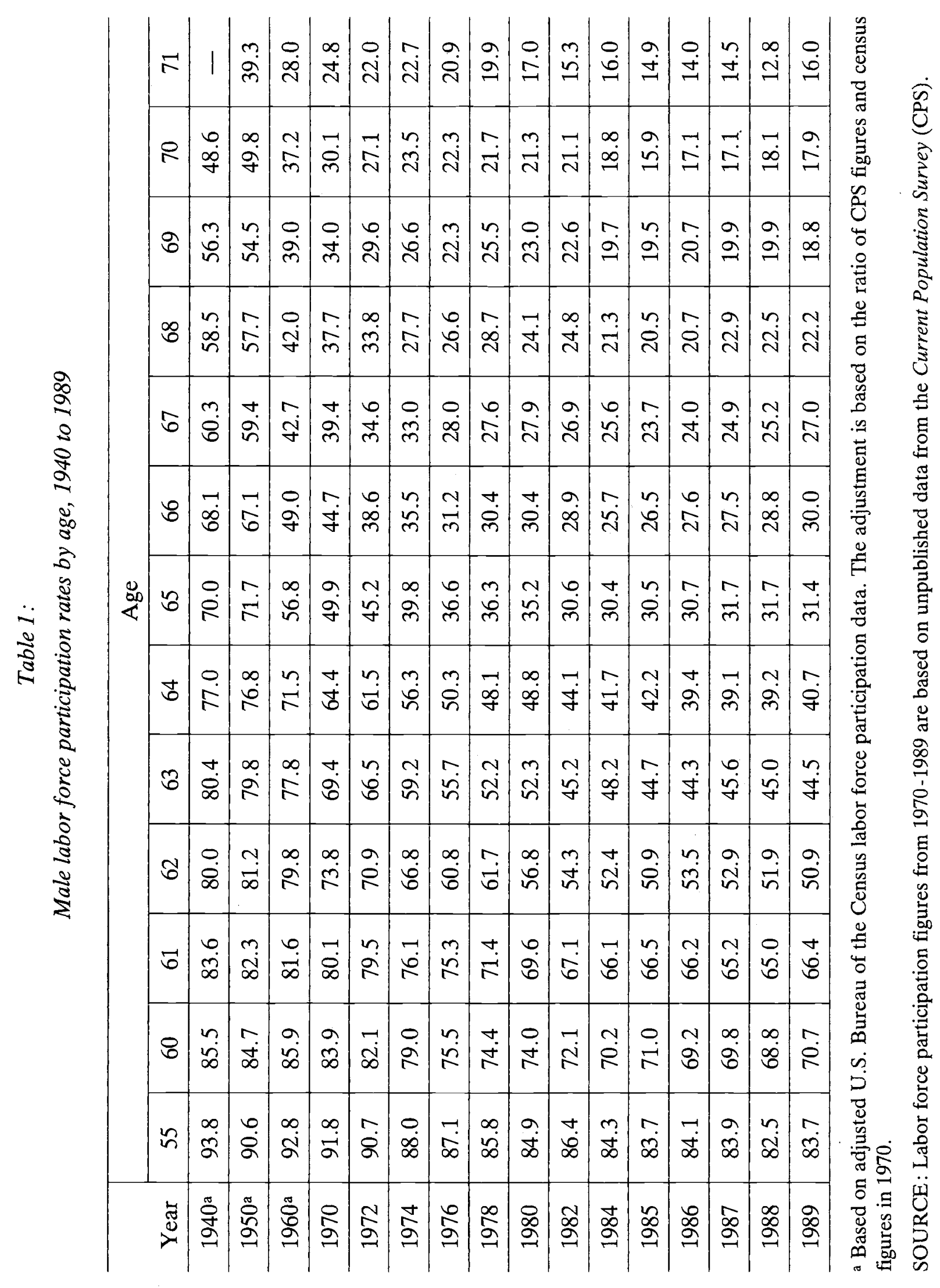




\section{A multi-year look at work and retirement}

Cross-sectional data provide a first clue that the 1980s were a far different decade than the 1970s with respect to the work effort of older men. But it cannot distinguish between increases in work effort at older ages that are the result of delayed retirement and those due to an increased return to work after retirement. To make such distinctions, it is necessary to follow individual workers through these transitions. And this can only be done with panel data. The great majority of multi-period research on retirement has been done with two such data sets: The Retirement History Survey and the National Longitudinal Survey. Unfortunately both these surveys followed cohorts of men who reached retirement age in the early 1970s. Neither provides information on work and retirement decisions in the 1980s. A major new data set, the Health and Retirement Survey sponsored by the National Institute for Aging will begin to follow a cohort of men and women aged 50 to 62 beginning in 1992. This will provide valuable information on the work and retirement decisions of older workers in the 1990s. But these data are several years away from the time they can be effectively used.

\subsection{Data}

There is only one United States panel study that can be used to compare the work and retirement decisions of men who retired in the 1970s with those who did so in the $1980 \mathrm{~s}$. We use this data set, the Panel Study of Income Dynamic (PSID), in this study. The PSID has interviewed a representative sample of some 5,000 families annually since 1968 . It provides data on a representative sample of men who worked full-time and retired during this period. All PSID data are weighted by the most recent individual weight for the particular statistics being estimated. We use the 1987 cross-year, response-file. (A more complete discussion of these data is provided in Survey Research Center 1984). All persons included in our analysis were in the PSID for the full 20-year period, 1968-1987. Those persons who died or disappeared from the survey are in the nonresponse files of the PSID, but are not included in our analysis.

We investigate the labor market transitions of older men in the PSID. We define older men as those reaching the age of 50 at some point during the life of the panel. To be included in our sample of older men, these men had to be household heads, work a large number of hours, and then leave the labor force or reduce their work hours by a significant percentage. Specifically, if a male respondent in the PSID reports being a household head and at least 50 years old and subsequently we have at least three consecutive years $(t-1, t$, $t+1)$ of information on him in which he reports working at least 1000 hours in year $t-1$, and reports at least a 50 percent reduction in his annual hours of work one year later in $t+1$, then that individual is included in our sample and is defined as having retired in year $t$. Year $t-1$ is classified as the last year of full-time career work, year $t$ is defined as a transition year or, the year in which retirement occurred, and year $t+1$ is defined as the first full year in retirement.

Our definition of retirement is necessary because of the data limitations imposed by the PSID. Until 1985, information was only gathered on the last or current job held and on total hours of work during the previous year. We do not know when the retirement or hours reduction occurred during this one year interval; we only know that a change in hours occurred during the interval. Hence, we will erroneously classify some individuals who left one job during the interval, were retired for a small amount of time, and then took another 
full-time job during that interval as having made no transition. This is because the change in total hours experienced may be too small to fit the 50 percent reduction criterion and no information is provided on the old job if a new job is taken before the interview.

We experimented with other definitions of retirement. Defining retirement as a reduction in annual hours from 1000 or more to 500 or less produced results similar to the ones reported in this paper. We also used a self-reported retirement definition in a previous study (Anderson, Burkhauser, and Slotsve, 1991). We chose not to use this self-reported measure here because it tended to exclude the partially retired -i. e., those working fewer hours on the same or some other job - and the sample sizes were small. Finally, we tried a 50 percent reduction in hours approach but restricted the analysis to men over the age of 57. Again, the results were similar to the ones reported here, but the sample sizes were smaller and the variances were larger.

\subsection{Theory}

We argue that older workers in a full-time job have two distinct decisions to make. The first is whether to retire from the career job. The second, conditional on retiring from such a career job, is whether to remain out of the labor market (permanent retirement) or to return to work. Reentry may be to a full or part-time job. These decisions depend upon individual expectations of the uncertain future values of health, marital status, remaining lifespan, pension benefits, social security benefits, labor market conditions and status. Following Rust (1989) and Berkovec and Stern (1991) we model individual retirement decisions in a dynamic programming framework.

For simplicity, individuals are assumed to be risk-neutral expected utility maximizers without access to capital markets. At time $t$ the present discounted value of an expected utility function of the form:

$$
V(t)=\operatorname{Max} \sum_{k=t}^{\infty} \beta^{k-t} E_{t}[U(t)]
$$

is maximized where $\beta$ is a fixed discount factor, and $E_{t}$ is an expectations operator where expectations are taken with respect to information available at the end of period $t-1 . U(t)$ denotes the utility at time $t$.

The utility function while on the career job is:

$$
U_{c}(t)=W(t)-C_{F}(t)
$$

where $W(t)$ is the wage at time $t$ and $C_{F}(t)$ is the disutility of labor when working full-time. $C_{F}(t)$ is assumed to increase as health deteriorates. We will assume that $C_{F}(t)$ is increasing in $t$ (that is, $C(t)$ increases with age). Finally, we will assume that $U_{c}(t)$ is decreasing in $t$. Wages typically rise over the early part of working life but decline with age. As wages fall and health deteriorates, the incentives to retire will increase. While wages may be increasing or decreasing in $t$, the last assumption implies that if the wage is increasing in $t$, it is increasing less than the disutility of labor in increasing. This implies that the utility of the career job is strictly decreasing in $t$.

The utility function for those who are retired and not working is :

$$
U_{R}(t)=R B\left(t^{\prime}\right)
$$

where $R B\left(t^{\prime}\right)$ denotes the annuitized value of retirement benefits given retirement in period $t^{\prime}\left(t^{\prime}<t\right)$. This includes benefits from employer pensions and social security. By definition, $U_{R}(t)$ is constant in $t$ given retirement occurred prior to date $t$. 
The utility function for those who are retired from the career job but who then work full-time is given by:

$$
U_{F}(t)=\alpha_{F} R B\left(t^{\prime}\right)-C_{F}(t)+W_{F}(t)
$$

where $\alpha_{F}$ denotes the percentage of the full-time retirement benefits received if working full-time. $W_{F}(t)$ denotes the period $t$ full-time wage. $\alpha_{F} R B\left(t^{\prime}\right)$ is decreasing in $t$. Thus, $U_{F}(t)$ is strictly decreasing in $t$.

The utility function for those who retired from the career job but who work part-time is given by:

$$
U_{p}(t)=\alpha_{p} R B\left(t^{\prime}\right)-C_{p}(t)+W_{p}(t)
$$

where $\alpha_{p}$ denotes the percentage of the full-time retirement benefits received if working part-time. $C_{p}(t)$ denotes the disutility of labor when working part-time in period $t$, and $W_{p}(t)$ denotes the period $t$ part-time wage. Once again, $\alpha_{p} R B\left(t^{\prime}\right)$ is decreasing in $t$. As a result, $U_{p}(t)$ is strictly decreasing in $t$. We will assume that $C_{F}(t)>C_{p}(t) . C_{i}(t), i=P, F$, is not observed by the econometrician.

$\alpha_{i}, i=P, F$, is a function of actual earnings, the threshold earnings level, age, and the percentage reduction in social security benefits. To be consistent with social security regulations, $\alpha_{i}$ is assumed to be less than or equal to one for those aged 62 and over and equal to one for individuals less than age 62 . The actual per period dollar value of social security benefits, however, strictly increases with continued work.

The optimal time to retire from a career job, denoted $t^{*}$ occurs when $U_{c}(t)=U_{R}(t)$. This calculation only involves a comparison of current period utility levels, as opposed to the present discounted values, and the solution $t_{R}$ is unique because $U_{c}(t)$ is strictly decreasing in $t$ and $U_{R}(t)$ is constant in $t . t_{R}$ is the optimal time to leave the career job if the only option is permanent retirement.

For $t^{\prime}<t_{R}, \alpha_{F}$ is calculated and $U_{F}\left(t^{\prime}\right)$ compared with $U_{c}\left(t^{\prime}\right)$. This can result in two outcomes. First, $U_{F}\left(t^{\prime}\right)<U_{c}\left(t^{\prime}\right)$ for all $t^{\prime}<t_{R}$ so one would never retire from the career job and re-enter in a full-time job. Second, for some, $t^{\prime}=t_{F}<t_{R}, U_{F}\left(t^{\prime}\right)=U_{c}\left(t^{\prime}\right)$ in which case one would retire from the career job and eventually take full-time work at time $t_{F}$. In a similar manner, $t_{p}$ is calculated as the time to retire from the career job and move to part-time work.

Finally, $\operatorname{Max}\left\{V\left(t_{R}\right), V\left(t_{p}\right), V\left(t_{F}\right)\right\}$, the present discounted value of each retirement option is calculated by those in the career job prior to period $t^{\prime}$. This implies the optimal time to retire from the career job, $t^{*}$, and the first retirement state exit.

As can be seen, in every period an optimal decision is determined. For future reference, we summarize the work decision in period $t$ with a polychotomous variable, $I(t)$, such that:

$$
\begin{aligned}
I(t) & =0 \text { if the individual is at the career job in period } t \\
& =1 \text { if the individual is retired, full-time work } \\
& =2 \text { if the individual is retired, part-time work } \\
& =3 \text { if the individual is full-time retired. }
\end{aligned}
$$

Once retired, the worker may not return to the career job at a later time. This is consistent with findings of Quinn, Burkhauser and Myers (1990). Finally, we represent the retirement "plan" by defining $I=\{I(t)\}$. Essentially we have a dynamic version of a static discrete choice model with a polychotomous variable.

It is important to note that the sequence $I(t)$ represents the retirement "plan" but this plan may not be realized. Only the first value of each sequence of $I(t)$ represents a decision 
observed by the econometrician. The reason is that new information may become available and the plan changed.

For example, an individual may decide at time $t$ to remain in the career job for three more periods and then retire into full-time retirement. This is represented by the sequence $\{0,0,0,0,3,3,3,3,3\}$ where expected lifespan is eight more periods. The current decision to remain in the career job, the first zero of the sequence, is observed by the econometrician. Anderson, Burkhauser, and Quinn (1986) found that retirement plans are revised in response to unexpected changes in health status, labor market conditions, and retirement program regulations. Suppose that in period $t+1$ social security benefits unexpectedly increase. In light of this new information, retirement plans may change to full-time retirement immediately. This is represented by the sequence $\{3,3,3,3,3,3,3,3\}$. Thus, the econometrician would then observe the move to full-time retirement. Finally, suppose in period $t+4$ the cost-of-living has unexpectedly increased. The individual may now decide to work full-time in period $t+4$ and then move back to full-time retirement. The sequence observed by the econometrician would be $\{0,3,3,3,1,3,3,3,3\}$. We will denote the observed sequence of decisions by $I^{\prime}$.

An individual's solution to the above optimization problem yields a sequence of decisions, $I^{\prime}$, observed by the econometrician. The hazard analysis we propose below examines this observed sequence in an attempt to analyze the determinants of the duration of retirement spells (subsequences of zeros, ones, twos and threes) and to examine the determinants of the exit probabilities from a spell. The reduced form approach we take also allows us to explicitly incorporate state variables such as social security benefits into our analysis.

\subsection{Description of the hazard model}

We estimate a continuous time hazard model of return to work. In a single transition model, the conditional probability of working during period $t$, given that the person is still retired at the beginning of $t$, is

$$
h(t)=g(t) /[1-G(t)]
$$

where $g(t)$ and $G(t)$ are the density and distribution functions of time to reentry. In our sample, we have two groups of retirees: (1) $N_{E}$ are retirees who take a job before the end of the survey $(T)$; and (2) $N_{R}$ are retirees who are still retired at $T$. The likelihood function in this single-transition hazard model has two components. First, for the $j^{\text {th }}$ retiree in group 1 , the probability of taking a job between a discrete interval $t_{t}$ and $t+e$ is:

$$
G_{j}(t+e)-G_{j}(t) \text {. }
$$

Second, for the $i^{\text {th }}$ retiree in group 2, the probability of not taking a job before $T$ is:

$$
1-G_{i}(T) \text {. }
$$

The likelihood functions is:

$$
\mathrm{L}=\prod_{\mathrm{j}=1}^{N_{E}}\left[G_{j}(t+e)-G_{j}(t)\right] \underset{\mathrm{i}=1}{\prod_{R}}\left[1-G_{i}(T)\right]
$$

where $t_{t}, T$, and $e$ are known.

In the model we estimate, we assume that the hazard rate, $h(t)$, has two components: an observable component measuring variation across individuals $\left(d_{l}\right)$ and a time profile 
measuring time-dependence $\left(d_{2}\right)$. We assume that $d_{l}$ is an exponential function of exogenous $X$ variables which measure the retiree's wage, pension wealth, health, and demographic characteristics:

$$
d_{l}=\exp \left(X^{\prime} B\right)
$$

where $B$ is a vector of coefficients. The second component, $d_{2}$, is assumed to have a Weibull form:

$$
d_{2}=\lambda p(\lambda t)^{p-1}
$$

$\lambda$ and $p$ are parameters to be estimated. The Weibull is a more general form of time dependence than the exponential; for example, if $p=1$, then the Weibull reduces to the exponential. If $p>1$, then the hazard rate is monotonically increasing with time (positive time dependence); if $p<1$ then the hazard is monotonically decreasing with time (negative time dependence). We also experimented with other parametric models: normal, logistic, and Gompertz. Results were similar to those reported here and are not included in this paper. We ignore unmeasured heterogeneity in this model. We also do not include any timevarying covariates in the $\mathrm{X}$ vector. The model is estimated using LIMDEP software.

The $\mathrm{X}$ variables measure individual characteristics, job characteristics, and wealth. The individual characteristics are the age at retirement, whether the individual reports a health limitation in the year before retirement, and whether the individual graduated from high school. The job characteristics are the real hourly wage in the year before retirement and the occupation of the job held before retirement. To measure occupation, we use three dummy variables for professional or managerial position, unskilled or service labor, and operative jobs. Finally, we include variables measuring the amount of real social security benefits and the amount of real other retirement income received in the first retirement year. Because we are interested in determining whether the speed with which retirees return to work has changed over the period 1968-1987, we include a dummy variable to measure whether retirement occurred in the 1980 s or prior to the $1980 \mathrm{~s}$.

\subsection{Results}

In Table 2 we report the results of our hazard analysis. We find that those who are health or education limited are less likely to return to work following retirement, but that age at retirement is not a significant factor. Higher skilled white or blue collar workers are more likely to return to work than workers with lower skills, but the wage rate on the preretirement job is not a significant factor in this decision. Real social security and employer pension benefits are important and the higher such benefits, the less likely is a return to work. Even when these characteristics are controlled, however, we still find that those who retired in the 1980s are more likely to return to work. The time dependence parameter is not significantly different from one indicating no time dependence.

These results mirror those found in behavioral studies of retirement. They suggest that the same socio-economic variables that influence retirement in the first place also affect duration in that state. Importantly we find that retirement is not a permanent state. Work after retirement is common and this phenomenon grew in the 1980s.

Those with poor health or poor job skills both retire early and stay retired. Those with a better health and with higher job skills are more likely to return to work. But this is offset by the higher social security and employer pensions benefits that such workers are likely to get. 
Table 2:

Hazard model of the duration in full retirement ${ }^{\text {a }}$

\begin{tabular}{|c|c|c|c|}
\hline Variable & Coefficient & Standard error & $\begin{array}{l}\text { Variable Mean } \\
\text { (standard error) }\end{array}$ \\
\hline Constant & -.933 & .533 & $\begin{array}{l}1.00 \\
(.000)\end{array}$ \\
\hline Age at retirement & -.001 & .009 & $\begin{array}{l}59.130 \\
(5.463)\end{array}$ \\
\hline Health limitation before retiring & $-.404^{* *}$ & .109 & $\begin{array}{l}.186 \\
(.390)\end{array}$ \\
\hline Professional/manager before retiring & $.406^{* *}$ & .113 & $\begin{array}{l}.236 \\
(.425)\end{array}$ \\
\hline Unskilled/service work before retiring & -.181 & .109 & $\begin{array}{l}.178 \\
(.383)\end{array}$ \\
\hline Operative before retiring & $.230^{* *}$ & .102 & $\begin{array}{l}.231 \\
(.422)\end{array}$ \\
\hline High school graduate & $.172^{*}$ & .091 & $\begin{array}{c}.471 \\
(.500) \\
\end{array}$ \\
\hline $\begin{array}{l}\text { Real social security benefits during } \\
\text { retirement (divided by } 1,000 \text { ) }\end{array}$ & $-.095^{* *}$ & .018 & $\begin{array}{c}2.581 \\
(3.625)\end{array}$ \\
\hline $\begin{array}{l}\text { Real other retirement income } \\
\text { (divided by } 1,000 \text { ) }\end{array}$ & $-.052^{* *}$ & .007 & $\begin{array}{c}3.087 \\
(7.469)\end{array}$ \\
\hline $\begin{array}{l}\text { Real hourly wage retirement } \\
\text { (divided by } 100 \text { ) }\end{array}$ & -.738 & .870 & $\begin{array}{l}.109 \\
(.076)\end{array}$ \\
\hline Retired during the 1980 s & $.515^{* *}$ & .082 & $\begin{array}{c}.539 \\
(.499) \\
\end{array}$ \\
\hline Lambda & $.337^{* *}$ & .024 & . \\
\hline p (time dependence) & $.980^{* *}$ & .065 & \\
\hline Log likelihood & -876.54 & & \\
\hline
\end{tabular}

* Significant at the 1 percent level.

** Significant at the 5 percent level.

a The base year for the real wage and benefit calculations is 1987 . 
Those retiring in the 1980 s were significantly faster in returning to work. We expect that this may be an underestimate of the cohort effect in our data where we use only the response file of the PSID. It is likely that our sample of 1970 retirees is healthier and of a higher socio-economic class than the attriters from this cohort. Because we track this cohort for a longer time following retirement than those retiring in the 1980s, this bias is likely to be greater for them than for the cohort of 1980 retirees.

\subsection{Comparing pre- and post-retirement jobs}

As we have seen, work after retirement is a common event and one that occurred more rapidly following retirement in the 1980s than in the 1970s. And work after retirement is an event that is sensitive to economic policy variables. But what kind of jobs do retired workers return to? In formulating public policy it is important to know not only the speed at which retired workers take jobs, but the nature of these jobs and how they vary from their previous full-time jobs.

Table 3 shows the occupation of workers in their career job and in the first job they take following retirement. In general, post-retirement jobs tend to be in the same occupation as career jobs. Those with high level career jobs tend to have high level post-career jobs. Seven in ten skilled white collar workers continue in that occupation after leaving their career job. Another 16 percent move to skilled blue collar jobs. Only 14 percent move to unskilled jobs.

Table 3:

Occupational change following retirement

(vertical percentages)

\begin{tabular}{l|c|c|c|c|c}
\hline \multirow{2}{*}{ New job occupation } & \multicolumn{5}{|c}{ Career job occupation } \\
\cline { 2 - 6 } & $\begin{array}{c}\text { White collar } \\
\text { skilled }\end{array}$ & $\begin{array}{c}\text { White collar } \\
\text { unskilled }\end{array}$ & $\begin{array}{c}\text { Blue collar } \\
\text { skilled }\end{array}$ & $\begin{array}{c}\text { Blue collar } \\
\text { unskilled }\end{array}$ & Total \\
\hline White collar skilled $^{\mathrm{a}}$ & $70 \%$ & $5 \%$ & $32 \%$ & $4 \%$ & $82(23)$ \\
\hline White collar unskilled $^{\mathrm{b}}$ & $5 \%$ & $61 \%$ & $10 \%$ & $13 \%$ & $74(21)$ \\
\hline Blue collar skilledc $^{\mathrm{c}}$ & $16 \%$ & $7 \%$ & $45 \%$ & $3 \%$ & $38(11)$ \\
\hline Blue collar unskilled $^{\mathrm{d}}$ & $9 \%$ & $27 \%$ & $13 \%$ & $79 \%$ & $156(45)$ \\
\hline Total & $88(25)$ & $75(21)$ & $31(9)$ & $156(45)$ & 350 \\
\hline a professionals, managers & \multicolumn{7}{c}{$\mathrm{b}$ clerical, sales, services } & \multicolumn{2}{c}{ crafts } & doperatives, farms \\
\hline
\end{tabular}

Those with low level career jobs, unskilled blue collar jobs, have low level post-career jobs. Almost eight in ten unskilled blue collar workers continue in such occupations after retirement. Another 13 percent go to unskilled white collar jobs. 
Those with middle-level career jobs have a bit more movement but career skilled blue collar workers still tend to hold either a skilled blue or white collar job following retirement, and unskilled white collar career job holders tend to hold either a post-retirement unskilled white or blue collar job.

Thus, while there is some movement across white and blue collar positions as workers move from career to post-career work, there is very little movement up or down the skill level. Skilled career workers tend to stay in skilled positions following retirement and unskilled workers tend to stay in unskilled positions in post-retirement work.

Perhaps the most surprising finding in our comparison of career and post-career work comes in Table 4 which looks at hourly wage rates. Hourly wage rates did not significantly influence the speed of return to work and there is more variation in career and post-career wage patterns than we expected. While in general those in lower wage career jobs had lower wage post-retirement jobs, many received higher wages. We also expected higher wage career job holders to have substantial drops in hourly wage rates in their post-retirement jobs. While this did occur to some extent, almost seven in ten continued to receive high hourly wages. Thus, while it does appear that there is some drop in post-retirement hourly wages, the variation in outcomes is much greater than expected.

Table 4:

Change in wage rate (vertical percentage)

\begin{tabular}{l|c|c|c|c|c}
\hline & \multicolumn{5}{|c}{ Career job wage rate } \\
\cline { 2 - 6 } New job wage rate & $\begin{array}{c}\$ 0-5 \\
\text { per hour }\end{array}$ & $\begin{array}{c}\$ 5-\$ 10 \\
\text { per hour }\end{array}$ & $\begin{array}{c}\$ 10-\$ 15 \\
\text { per hour }\end{array}$ & $\begin{array}{c}\$ 15+ \\
\text { per hour }\end{array}$ & Total \\
\hline$\$ 0-\$ 5$ per hour & $41 \%$ & $31 \%$ & $15 \%$ & $10 \%$ & $104(22)$ \\
\hline$\$ 5-\$ 10$ per hour & $43 \%$ & $37 \%$ & $23 \%$ & $7 \%$ & $134(29)$ \\
\hline$\$ 10-\$ 15$ per hour & $11 \%$ & $16 \%$ & $25 \%$ & $15 \%$ & $79(17)$ \\
\hline More than $\$ 15$ & $6 \%$ & $23 \%$ & $37 \%$ & $68 \%$ & $148(32)$ \\
\hline Total & $101(22)$ & $150(32)$ & $120(26)$ & $94(20)$ & 465 \\
\hline
\end{tabular}

The results in Tables 5 and 6 are much more in keeping with expectations. Table 5 compares hours worked per week on career and post-retirement jobs. Only about one worker in ten worked less than 40 hours per week on his career job while nearly six in ten did so on their post-career job. This is the most obvious difference between career and postcareer work. Only a minority of those who return to work following retirement from a fulltime career job do so full-time. This is less true of the four in ten workers who worked more than 40 hours on their career jobs; but even among these intensive workers, more than one half moved to below 40 hours per week jobs. 
Table 5:

Change in hours worked per week

(vertical percentage)

\begin{tabular}{l|c|c|c|c}
\hline \multirow{2}{*}{$\begin{array}{l}\text { New job hours } \\
\text { worked }\end{array}$} & \multicolumn{4}{|c}{ Career job hours worked } \\
\cline { 2 - 5 } & $\begin{array}{c}\text { less than } 40 \\
\text { hours }\end{array}$ & 40 hours & $\begin{array}{c}\text { more than } 40 \\
\text { hours }\end{array}$ & Total \\
\hline Less than 40 hours & $85 \%$ & $56 \%$ & $56 \%$ & $281(59)$ \\
\hline 40 hours & $13 \%$ & $26 \%$ & $20 \%$ & $127(27)$ \\
\hline More than 40 hours & $2 \%$ & $8 \%$ & $24 \%$ & $66(14)$ \\
\hline Total & $54(11)$ & $223(47)$ & $197(42)$ & 474 \\
\hline
\end{tabular}

Table 6:

Changes in weeks worked per year

(vertical percentage)

\begin{tabular}{l|c|c|c|c}
\hline \multirow{2}{*}{$\begin{array}{l}\text { New job weeks } \\
\text { worked }\end{array}$} & \multicolumn{4}{|c}{ Career job weeks worked ${ }^{\mathrm{a}}$} \\
\cline { 2 - 5 } & $\begin{array}{c}\text { less than } 40 \\
\text { weeks }\end{array}$ & $40-49$ weeks & $50+$ weeks & Total \\
\hline Less than 40 weeks & $87 \%$ & $85 \%$ & $73 \%$ & $377(80)$ \\
\hline $40-49$ weeks & $8 \%$ & $10 \%$ & $6 \%$ & $39(8)$ \\
\hline 50 weeks or more & $4 \%$ & $6 \%$ & $21 \%$ & $54(11)$ \\
\hline Total & $46(10)$ & $241(51)$ & $183(39)$ & 470 \\
\hline
\end{tabular}

a All workers in career jobs worked at least 25 weeks.

Table 6 reinforces this view of reduced work time in post-retirement jobs. Only one in ten career job holder worked less than 40 weeks per year, while eight in ten post-retirement jobs were less than 40 weeks per year. Of the four in ten workers who were employed for more than 50 weeks per year in their career job, more than seven in ten worked less than 40 weeks in their post-retirement jobs.

Jobs held following retirement from a career job differ most dramatically in hours worked. Clearly older men who return to the workforce do not do so in full-time employment. The great majority of such jobs are part week or part year in nature. However, there is not as much movement down the job ladder as might have been expected. While it is true that unskilled career job holders continue in unskilled occupations, the great majority of 
high skill workers continue in high skill occupations. It is clearly not the case that all postcareer jobs are unskilled. This is also the trend with respect to wages. The distribution of hourly wage rates on post-career jobs is much closer to career job wage rates than expected. A majority of those in high hourly wage rate career jobs continue to receive that high wage on their post-career jobs.

\subsection{Discussion}

The 1970s were a period of sharp decline in the labor force participation rates of older men. Despite the most serious economic slump since the 1930s, the rate of decline in participation slowed in the first part of the 1980s and rose slightly during the strong recovery that followed. Here we have shown that part of this turnaround was caused by a more rapid return to work of men who had retired from full-time jobs. We saw that the decision to return to work is influenced by the same economic forces that have been found to affect the initial decision to retire.

The major difference between career and post-retirement jobs are in hours worked. This is undoubtedly caused by a combination of economic incentives and the taste of older workers. During the period of our analysis, social security benefits were substantially reduced if a person worked full-time. Prior to 1972 the marginal tax on work reached 100 percent. This was reduced to 50 percent in 1973 and 33.3 percent in 1990 but still provides an incentive to retire and to do so permanently. In addition, the amount permitted to be earned without loss of social security benefits increased from $\$ 2,100$ in 1973 for all beneficiaries to $\$ 7,080$ in 1991 for those aged 62 to 64 and $\$ 9,720$ in 1991 for those aged 65 to 70 . For those over age 70 there is now no earnings test.

But it's also likely that a taste for reduced working hours increases with age. Gustman and Steiner, 1983, argue that the inability to contract for part-time work on their career job is a major factor in a worker's retirement decision. This is compounded by the fact that employer pension plans that provide benefits based on some combination of highest earnings sharply penalize part-time work.

As public policy is developed to increase the labor force participation of older workers, it is important to distinguish policies that are likely to increase the age at which a worker leaves a full-time career job and policies that will increase movement into a job, usually in a part-time job, for those who are already retired.

We argue here that retirement trends are not exogenous. Current and planned changes in social security legislation will have some effect in delaying retirement from a full-time career job. But this legislation is not likely to dramatically affect this aspect of retirement. Employer pension plans that significantly discourage work on a career job, often at the earliest possible retirement age, will continue to be a strong inducement to retire. Only substantial changes in these private labor contracts are likely to significantly affect the age workers leave their career job.

But part-time work after retirement is much more susceptible to changes in social security policy and it is very likely that the increase in this kind of post-career work behavior that we show in the 1980 s will continue. Small changes in public policy could further encourage part-time post-retirement work. For instance: the total elimination of the social security earnings test, an earlier phase-in of an actuarially fair delayed retirement credit for work past age 65 , exemption of social security recipients from social security taxes on parttime earnings, or the suspension of the fringe benefit requirements under section 89 of the 
Tax Code for part-time older workers. (See Burkhauser and Quinn, 1990 for a greater discussion.) Each of these proposals would reduce the current penalties on work found in current federal tax and transfer policy.

Surveys of older workers suggest that many older workers would like to retire gradually, and incorporate a period of partial retirement into their transition from full-time work to complete labor force withdrawal (see Quinn and Burkhauser, 1991). Policies that facilitate this desire by making it less costly for firms to hire part-time workers and less costly for older workers to accept part-time employment will allow these desires to be accommodated and retain productive workers in the labor force.

\section{REFERENCES}

ANDERSON, K., BURKHAUSER, R. and QUINN, J. (1986): "Do Retirement Dreams Come True? The Effect of Unanticipated Events on Retirement Plans". Industrial Labor Relations Review, 39 (July): 518-526.

ANDERSON, K., BURKHAUSER, R. and SLOTSVE, G. (1991): "Work After Retirement from 1968-1987: Evidence From the Panel Study of Income Dynamics". Paper presented at the Annual Meetings of the European Society of Population Economists, June 1991, Pisa, Italy.

BERKOVEC, J. and STERN, S. (1991): “Job Exit Behavior of Older Men”, Econometrica, Vol. 59 (1): $189-210$.

BURKHAUSER, R. and QUINN, J. (1990): "Economic Incentives and the Labor Force Participation of Older Workers". In L. Bassi and D. Crawford (eds.), Research in Labor Economics (Vol. 11). New York: JAI Press: 159-179.

BURTLESS, G. and MOFFITT, R. (1984): "The Effects of Social Security Benefits in the Labor Supply of the Aged". In H. Aaron and G. Burtless (eds.), Retirement and Economic Behavior, Washington, DC: The Brookings Institution: 209-236.

FIELDS, G. and MITCHELL, O. (1984): "The Effects of Social Security Reforms on Retirement Ages and Retirement Incomes". Journal of Public Economics 25 (November): 143-159.

GUSTMAN, A. and STEINMEIER, T. (1983): "Minimum Hours Constraints and Retirement Behavior". Contemporary Policy Issues, 3 (April): 77-91.

GUSTMAN, A. and STEINMEIER, T. (1985): "The Social Security Reforms and Labor Adjustments of Older Individuals in the Long Run". Journal of Labor Economics, 3 (April): 237-253.

QUINN, J., BURKHAUSER, R. and MYERS, D. (1990): Passing the Torch: The Influence of Economic Incentives on Work and Retirement, Kalamazoo, MI: W. E. Upjohn Institute for Employment Research.

QUINN, J. and BURKHAUSER, R. (1991): "Plans and Preferences of Older American Workers". Metropolitan Studies Program Working Paper, The Maxwell School. Syracuse, NY: Syracuse University.

RUHM, C. (1991): "Bridge Jobs and Partial Retirement", Journal of Labor Economics, Vol. 8, No. 4: 482-501.

RUST, J. (1989): “A Dynamic Programming Model of Retirement Behavior”, in Economics of Aging, edited by D. A. Wise, 359-398. Chicago, IL.: The University of Chicago Press.

Survey Research Center (1984): User Guide to the Panel Study of Income Dynamics. Ann Arbor: ICPSR. 